\title{
Interpersonal Intimacy and Meaning of Life of Institutionalized Elders
}

\author{
Aziza Mahmoud Boughdady, Lecturer \\ Gerontological Nursing, Faculty of Nursing, Mansoura University \\ Soad Hassan Abd Elhameed, Assistant Professor \\ Gerontological Nursing, Faculty of Nursing, Mansoura University
}

\begin{abstract}
Interpersonal intimacy refers to the intimate, interpersonal relationships that are formed internally during interactions with other persons or groups. As well, aging is an important issue to address in an effort to help the elders live as healthy individuals and to enhance their sense of meaning in life, happiness, and interpersonal intimacy. Objective: Explore the interpersonal intimacy and meaning of life of institutionalized elders. Setting: The study was conducted in three of the governmental elderly homes in Dakahlia governorate namely; Dar Elamal, Dar Elmalak Mikhael in Mansoura city and Dar Elwalaa in Meet Ghamr city. Subjects: The study included 51 elderly selected from the previously mentioned settings. Tools: Four tools were used; Mini-Mental State Examination, Elders' Sociodemographic Characteristics and Health Profile Structured Interview Schedule, Interpersonal Intimacy Questionnaire and Meaning of Life Questionnaire. Results: The present study findings showed that males had a higher interpersonal intimacy and meaning of life than females $(P=0.01$ and $P=0.00)$. A positive significant correlation between interpersonal intimacy and meaning of life among the institutionalized elders $(P=0.03)$ was observed. Conclusion: Increase in interpersonal intimacy and meaning of life among elders are associated with the shorter duration of stay in the home, maintaining social relations outside the home, and positive perception of health. Recommendations: Caregivers in elderly homes should focus on increasing interpersonal intimacy and purpose in life among their residents by increasing socialization and interaction among elders, encourage participation in recreational activities, plan periodical meeting with elder's family members and friends.
\end{abstract}

Keywords: Interpersonal intimacy; Meaning of life; Institutionalized Elders; Nurse role.

\section{Introduction}

Interpersonal intimacy is the most essential part of human development. It refers to the intimate, interpersonal relationships that are formed internally during interactions with other persons or groups $^{(1)}$. These kinds of relationships are close, safe, reciprocal, and sharing. They involve not only sharing personal joy, anger, sadness, happiness, and subtle or intimate knowledge but also mutual understanding, trust, love, and care with others ${ }^{(2,3)}$. Also, it alleviates personal pressure, eliminate the sense of isolation, satisfy various psychological needs and provide the recognition required by individuals. In addition, it assists elderly people in coping with a loss of meaning of and changes in life $\mathrm{f}^{(4,5)}$. Various studies have indicated that interpersonal intimacy in elderly people is influenced by age, educational level, relationships with family and friends and self-perceived health status ${ }^{(6,7)}$.

The meaning of life is the life missions, goals, and various values of an individual. It is a process that generates positive or negative results under the influence of life experiences and situations. Greater purpose in life is associated with greater life satisfaction and shaping the sense of happiness ${ }^{(8-10)}$. Experiencing purpose in life is also described as being happy in everyday life and thinking positively in every situation that make the most of one's day and is expressed as a purposeful act. Elderly people's affirmation of life value often depends on whether they possess positive meanings of their present and past life experiences ${ }^{(11,12)}$. 
The number of elderly people has been increased gradually and the global population is rapidly ageing. Between 2013 and 2050, the proportion of the world's older adults is expected to double from about $11.7 \%$ to $21.1 \%^{(13,14)}$. In Egypt the aged 60 years and more was $7.9 \%$ in 2015 and is expected to reach $9.9 \%$ of the total population by $2030^{(15)}$. Older age frequently involves significant changes beyond the biological changes. These include shifts in roles and social positions, and the need to deal with the loss of close relationships. In response, older adults tend to select fewer and more meaningful goals and activities, optimize their existing abilities through practice and new technologies, and compensate for the losses of some abilities by finding other ways to accomplish tasks $^{(16)}$.

The increase in life expectancy lead to increase in the older adult population ${ }^{(17)}$. This threw the light on the increased demand for home care services to meet the needs of elderly people, particularly in case of the absence of formal caregivers, sociodemographic changes, and decline in health and functional status of elders. Now a days, the residential homes are becoming a preferred choice for many nuclear families to send their old member in case they fail to provide him with the necessary care he needs. Also, the elderly persons may take the decision to go voluntarily to the home because he feels lonely in his own home and has no body to care for $\operatorname{him}^{(18-20)}$. However, relocating an older adult in elderly home is a multifaceted process involving not only the older adult but also his family and working personnel $^{(20)}$. For the older adult, it is a stressful situation due to loss of his own home, admission to a new environment, loss of social relations with family members, relatives and friends, loss of autonomy and reduction of habitual activities which usually leads to immobility and dependence ${ }^{(21)}$. Institutionalization affects the elder's selfdetermination, lead to powerlessness and dependence due to the restricted home routine. It, also, leads to feeling of loneliness and social isolation. Social contacts, particularly with family and friends, usually decrease after admission to the elderly home especially with the increase in the duration of institutionalization. All these factors, if not properly tackled by working staff in elderly homes will affect the resident's wellbeing and quality of life ${ }^{(22)}$. These problems may cause interpersonal alienation, low intimacy, emptiness, despair, the lack of meaning in life and the inability to adapt to changes in life brought on by aging. Therefore, nurses working in elderly homes have an important role in promoting a higher degree of interpersonal intimacy and a higher appreciation of the meaning of life, thus enabling elderly to confront old age in a more positive manner, improve quality of life and reach successful aging ${ }^{(23)}$.

Nursing literature commonly addresses meaning in life, underpinning the importance of nurses helping people and their families not only in suffering and coping with illness but also finding meaning in these experiences ${ }^{(24-26)}$. Moreover, finding meaning in life is a subjective and unique process within the individual. The individual must perceive meaning because it cannot be invented. The nurse cannot show or tell people how they can find meaning. Neither can nurses create, point out or transfer meaning to another person; finding meaning in life needs an internal process and active participation. Though, nurses can walk along with elders, supporting the meaning-making process by questioning and empathic listening ${ }^{(27)}$. One way to experience meaning is to open up to other people's care, kindness and love. Furthermore, nurses working in elderly home have an important role in the context of suffering by helping elders and increase their capacity to switch personal tragedy into human growth and to convert despair into well-being by means of one's chosen attitude ${ }^{(28)}$.

In relation to interpersonal intimacy, the nurse may be required to focus on needs to build person-centered relationship because the interpersonal relationship is a 
key element in nursing. The nurse needs good communication skills when caring for the elderly in order to assess elders' condition and identify his needs this will help in implementing appropriate intervention and evaluate care. Also, nurses should motivate and encourage elderly home residents to build intimate interpersonal relations with each other, through sharing in different activities and maintaining good relations ${ }^{(29)}$. Moreover, respect elder's selfdetermination and autonomy are a focal principle in nursing ethics and is strongly linked to elder's sense of value and quality of life ${ }^{(27)}$.

Recent surveys of the older people in the world have centered on medical institutions and nursing homes, with comparatively few focusing on older people in elderly homes ${ }^{(2)}$. In addition, little research has directly examined the interpersonal intimacy and meaning of life of elderly people. Consequently, an investigation of the relationship between interpersonal intimacy and the meaning of life among the institutionalized elderly is necessary. This topic was selected partly because of the importance and lack of exploration of this issue.

\section{Aim of the Study}

This study aims to explore the interpersonal intimacy and meaning of life of institutionalized elders.

\section{Research Question}

What is the level of interpersonal intimacy and meaning of life of institutionalized elders?

\section{Materials and Method}

\section{Materials}

Design: The study followed a descriptive correlational research design.

Setting: This study was conducted in three of the governmental elderly homes in Dakahlia governorate namely; Dar Elamal,
Dar Elmalak Mikhael in Mansoura city and Dar Elwalaa in Meet Ghamr city.

Subjects: Of the total number of residents in the previous settings $(n=56)$ only 51 elders were fulfilling the study criteria which are; aged 60 years and above, able to communicate, and accept to participate in the study. Elderly with severe cognitive impairment, i.e., scoring less than 18 in the Mini-Mental State Examination, were excluded from the study.

Tools: The following four tools were used for data collection:

Tool I: Mini-Mental State Examination (MMSE)

This scale was adopted from Folstien $(1999)^{(30)}$. It was translated into Arabic language by El-Auqla $(2002)^{(31)}$. Validated and tested for its reliability $(\mathrm{r}=0.093)$ by Abd El Moniem (2012) ${ }^{(32)}$. It was designed for assessing the elder's cognitive function. It consists of 11 items that investigate the memory, orientation to time and place, attention, calculation naming, repetition, registration, language, praxis and copying of a design. This tool was used to exclude elders with severe degree of cognitive impairment from participation in the study:

- Sore of 24-30 indicates normal cognitive function.

- Score of 18-23 indicates mild cognitive impairment.

- Score of 0-17 indicates severe cognitive impairment.

Tool II: Elders Sociodemographic Characteristics and Health Profile Structured Interview Schedule

This tool was developed by the researchers after reviewing the related literature and used to collect the following data:

1. Sociodemographic characteristics of the elders such as age, sex, marital status, education, 
occupation before retirement and monthly income.

2. Data about institutionalization such as duration of stay in elderly home, feeling on admission, feeling now, decision of admission, satisfaction and taking a leave outside the home.

3. Health profile of elderly such as presence of comorbidities and perceived health status.

\section{Tool III: Interpersonal Intimacy}

\section{Questionnaire}

This tool was developed by the researchers after literature reviewing and guided by Chan et al. $(2015)^{(33)}$. It was used to measure intimacy between the elderly home residents, which indicates the quality of their relationship. It consists of 17 items, each item had three possible responses: 0 (No), 1 (Sometimes), and 2 (Yes). The total score of the questionnaire ranged from 0 to 34. The higher score represents greater intimacy/affection.

\section{Tool IV: Meaning in Life Questionnaire} (MLQ)

This questionnaire was adopted from Steger et al. $(2006)^{(34)}$. It was designed to assess the presence of and search for meaning in life. It consists of 10 items with two subscales: presence of meaning (Items number $1,4,5,6, \& 9$ ), and search for meaning (Items number 2, 3, 7, 8, \& 10). Options are given in 5 points Likert scale and each question gets score from 1 (Absolutely Untrue), 2 (Mostly untrue), 3 (Can't say true or false), 4 (Mostly true), and 5 (Absolutely true). The score of each subscale ranged from 5 to 25 and the total score of the scale ranged from 10 to 50 . The higher score indicates a greater meaning in life for the elders.

\section{Method}

- An official letter was issued from the dean of the faculty of Nursing-
Mansoura University to the directors of all elderly homes in Dakahlia Governorate. An approval was obtained after explanation of the aim of the study to all directors.

- The Arabic version of tool I (MiniMental State Examination) was used. It was validated and tested for its reliability $(\mathrm{r}=0.093)$ by Abd El Moniem (2012) ${ }^{(32)}$.

- Tool II (Elders Sociodemographic Characteristics and Health Profile Structured Interview Schedule) and tool III (Interpersonal Intimacy questionnaire) were developed by the researchers after a thorough review of literature.

- Tool IV (Meaning in Life Questionnaire was translated by the researchers into Arabic language and tested for reliability using Spearman's correlation coefficient $(\mathrm{r}=0.861)$.

- The content validity of the study tools was obtained by a jury of five experts in the related fields of the study (Gerontological nursing and Psychiatric nursing). The required corrections and modifications were done accordingly.

- Survey of all elderly homes available in Dakahlia Governorate was done in order to select the elders fulfilling the study criteria.

- A pilot study was carried out on 6 elderly patients from Elamal elderly club at Mansoura city to test clarity and feasibility of the tools and the approximate time needed for the interview. Accordingly, the necessary modifications were done.

- Each elderly was interviewed individually by the researchers after explaining the purpose of the study in the elderly home to collect the necessary data using the study tools. Thetime taken for data collection 
ranged from 15 to30 minutes for each elderly .

- The data collection covered a period of three months from the middle of December 2017 till the middle of March 2018.

\section{Ethical considerations:}

Ethical approval was taken from Mansoura University Faculty of Nursing Ethic Committee. Oral informed consent was obtained from the eligible elders after explanation of nature of the study. The elderly was informed that, their participation is voluntary and that they can withdraw from the study at any time. Anonymity, privacy of the study subjects and confidentiality of the data collected were assured.

\section{Statistical Analysis}

After data were collected it was revised, coded and fed to Statistical Package for Social Science Software version sixteen. Basic descriptive statistical analysis was carried out using; frequencies, means, standard deviations, and analytical statistics using; Chi Square $\left(\mathrm{X}^{2}\right)$, student t-test, and Spearman's correlation coefficient. The 0.05 and 0.01 levels were utilized as the cut off value for statistical significance. The given graphs were constructed using SPSS software.

\section{Results}

Table (1) shows the sociodemographic characteristics and presence of comorbidities of the institutionalized elders. Their mean age is $69.5 \pm 5.5$ years, $74.5 \%$ are males and Muslim, $56.9 \%$ are widows, $35.3 \%$ completed their secondary school education and $76.5 \%$ worked before retirement. Monthly income is reported to be enough by $64.7 \%$ of the study subjects. Only $21.6 \%$ of the study subjects had more than two chronic diseases and $37.2 \%$ had one chronic disease.

Table (2) illustrates that duration of stay in elderly home for less than 5 years was reported by $70.6 \%$ of the study subjects. The main reason for admission to elderly home is the absence of caregiver (43.1\%). Also, $72.5 \%$ of the study subjects decided voluntarily to move to the elderly home based on their own decision. $52.9 \%$ of the study subjects felt sad at time of admission to the elderly home and $49.0 \%$ felt sad now. $86.3 \%$ are satisfied with living in elderly home and $68.6 \%$ of the study subjects taking leave outside the home.

Figure (1) shows the perceived health status of the institutionalized elders. $51 \%$ of the study subjects perceived their health status as good and $9.8 \%$ reported very good health status.

Table (3) shows the distribution of institutionalized elders according to their interpersonal intimacy responses. $21.6 \%$ of the study subjects want to spend time together, $39.2 \%$ show love for each other, $60.8 \%$ show honesty and don't lie, $51 \%$ respect each other and $49 \%$ mentioned that live is better because of presence of such peers. Moreover, $37.3 \%$ of the study subjects reported that they are lucky to have such peers in life. The average total score for meaning of life was $19.49 \pm 8.41$.

Table (4) illustrates that, $9.8 \%$ of the study subjects understand the meaning of their life, have a clear sense of purpose and have a good sense of what makes life meaningful. While, $17.6 \%$ of the study subjects have no clear purpose in life. Moreover, $15.7 \%$ of the study subjects are looking for something that makes life meaningful and only $7.8 \%$ seeking for a purpose or mission for life. The average total score for meaning of life was $26.45 \pm 9.67$.

Table (5) shows a statistically significant relation between interpersonal intimacy mean score and meaning of life mean score regarding sex $(\mathrm{P}=0.01$ and $\mathrm{P}=0.00)$ and monthly income $(\mathrm{P}=0.00$, and $\mathrm{P}=0.04)$. In addition, a statistically significant difference was found between the study subjects' interpersonal intimacy and religion $(\mathrm{P}=0.00)$. 
Table (6) illustrates that a statistically significant relation was found between the study subjects' interpersonal intimacy and meaning of life regarding duration of stay $(\mathrm{P}=0.00$ and $\mathrm{P}=0.01$ respectively) and elders feeling now $(\mathrm{P}=0.02$ and $\mathrm{P}=0.03$ respectively). Also, a statistically significant relation between interpersonal intimacy and decision of admission to the home $(\mathrm{P}=0.01)$ and taking a leave outside the home $(\mathrm{P}=0.01)$.

Table (7) shows a significant positive correlation between the study subjects' interpersonal intimacy and meaning of life $(\mathrm{P}=0.03)$. Moreover, a positive significant correlation was found between meaning of life and perceived health status among the study subjects $(\mathrm{P}=0.05)$.

\section{Discussion}

Aging is an important issue to address in an effort to help elders to live as healthy as possible. All health and community services should cooperate to promote and maintain health. This can be achieved through fostering meaning in life, happiness, interpersonal intimacy and consequently improve quality of life ${ }^{(18)}$. The primary goal of elderly home is to help its residents to maintain interest in life in order to attain successful aging. Therefore, the aim of this study is to explore the interpersonal intimacy and meaning of life of institutionalized elders.

The present study findings revealed that the age of institutionalized elders ranged from 60 to 78 years, with a mean of $69.5 \pm 5.5$ years. More than two thirds of the subjects were males and more than half of them were widows (table 1). This result indicates that male elders can't live alone in their own home after the death of their wife. The same findings were reported from other studies carried out in India by Kalavar and Jamuna $(2008)^{(37)}$, Rathaur and Mishra $(2016)^{(38)}$ and in Taiwan by Niu et al. $(2016)^{(2)}$. In Egypt (Cairo and Giza Governorate), Hassan et al. $(2017)^{(35)}$ reported that the age of the institutionalized elders ranged from 60 to less than 80 years. Also, Ahmed $(2015)^{(36)}$ in a study in Dakahlia Governorate reported that the mean age of the institutionalized elders was $69.21 \pm 7.08$ years and that males were more than females in his study.

It is not surprising that the studied elders accepted their relocation to the elderly home. This may be because the majority of them were admitted voluntary (table 2). This may be rationalized as the admission to the elderly home was the only available option for them and they had no other choice due to the absence of someone to care for them at home or because they feel lonely at home or because of family problems. However, on admission to the home most elders reported being sad but now they cope with institutionalization and adjust with the current situation (table 2). The same reasons were reported in other studies ${ }^{(35,36)}$. Also, Gurung and Ghimire (2014) ${ }^{(39)}$ and Singh and Mahato $(2014)^{(40)}$ reported that, half of the cases were brought to old age homes because of having no one to take care of them at their own home followed by conflicting relationship with family. Furthermore, the results of the present study are in agreement with a study carried out in Malaysia by Hoe et al. (2018) ${ }^{(18)}$ who stated that, the institutionalized elders seems satisfied with their current life.

Moderate interpersonal intimacy level was reported in the present study (table 3 ). This finding may be related to age related changes which tend to make older people more sensitive to the changes in the physical environment. This may impair their ability to adapt to new environments and interact with strange people in a new setting. This result is in the same line with those of Niu et al. $(2016)^{(2)}$. Moreover, the meaning of life level among the study subjects was also moderate (table 4). This result may reflect the believe of elders that attaining aging and retirement means end of their duties towards their work, family, and community and may be also end of life. So, understanding how elderly home residents perceive purpose and 
meaning in life is critical for improving the residents' quality of life by providing necessary care to meet their needs and attaining successful aging.

The results of the present study revealed that males had a higher interpersonal intimacy relationship and higher meaning of life than females (table 5). This may be related to the fact that relocation is a stressful event that requires adjustment and coping which may take longer period for females than males. In addition to the high emotions of women and the strong tie with their families. This beside the unfamiliar environment of the elderly home with its restricted routines. This result is in agreement with a study carried out in Sweden by Hedberg et al. (2013) ${ }^{(10)}$ who reported that, men had a higher purpose in life than females while contradicts that of Musichet al. $(2018)^{(9)}$ who reported that female had high purpose in life because they were more likely to have high social support, high resilience, strong reliance on faith, high health literacy, and better health.

Religion plays an important and often central role in the lives of elderly, and may have a positive value in filling a void and supplying strength and meaning in $\operatorname{life}^{(40)}$. Having purpose in life is central to combat meaninglessness. Religion is concerned with meaning-making and aims to address fundamental questions of meaning and purpose in life through its beliefs, teachings and rituals ${ }^{(41)}$. The results of the current study showed that the institutionalized Christian elders had a higher mean score of interpersonal intimacy than institutionalized Muslims (table 5). This may be related to the increased number of caregivers in Christian elderly home than in the other study settings. Also to the type of care and support provided to the elders from different volunteers and organizations.

Occupation before retirement affected significantly elders interpersonal intimacy and meaning of life (table 5). This may be explained by the fact that occupation gives the person a sense of power and role in the community, as well as a purpose in life. This result is in agreement with other studies conducted in Sweden by Hedberg et al. $(2013)^{(10)}$ and in Taiwan by Niu et al. $(2016)^{(2)}$. Also, elder's income affected significantly interpersonal intimacy and meaning of life (table 5). This may be because the adequacy of income helps the elders to meet their basic needs, participate in recreational and social activities that promote social interaction. The same results were reported in China by Liu $(2000)^{(42)}$ who stated that financially stable elderly people possessed relatively high levels of independence and therefore had confidence and a sense of security in interpersonal interactions.

Furthermore, the results of the present study revealed that the duration of stay in the elderly home affected significantly interpersonal intimacy and meaning of life of the study subjects (table 6). As elderly who reported longer periods of residence showed less interpersonal intimacy. This may be related to elders' feeling lonely due to the lack of socialization. On the same line, a study carried out in Finland by Teeri et al. $(2006)^{(43)}$ found that residents felt lonely and there was a significant relation between duration of residence and meaning of life. As regards meaning of life, the study revealed that the longer the duration of stay in the home the less the meaning of life (table 6). This may be due to age related changes, increase deterioration in bodily functions, decline in health status, and decreased perceptions of meaning of life.

Families remain the single most important source of aid and support for elders. This was observed in the present study where taking a leave outside the elderly home to visit families and friends was significantly associated with higher interpersonal intimacy level. This result is in agreement with Hou $2004^{(44)}$, and Waite and Das $(2010)^{(45)}$ who reported that elderly people who obtained support from family and friends had more interpersonal intimacy. 
Meaning and purpose in life are parts of intrapersonal self-transcendence, which is fundamental to elderly home residents wellbeing and quality of life ${ }^{(27)}$. The results of the present study showed that there is a positive significant correlation between meaning of life and perceived health status of the institutionalized elders (table 7). This may be related to the fact that the higher the level of perceived health status of elders will lead to increase level of independence. This in turn will enable the elderly to choose their desired lifestyles, obtain support from others, and to achieve a more positive perception of the meaning of life. This finding is in agreement with other studies carried out by $\mathrm{Wu}$ et al. (2010) ${ }^{(46)}$ and Musich et al. $(2018)^{(9)}$. Moreover, the results of the present study revealed that, there is a positive significant correlation between the meaning of life and the interpersonal intimacy (table 7). This result supports those of Stillman et al. (2009) ${ }^{(47)}$ and Niu et al. $(2016)^{(2)}$.

The study results signify that meaning and purpose in life illustrate a set of views and attitudes that make the world intelligible, such as having goals to perform work or a task that is experienced to be meaningful, strove for by working creatively, finding solutions in difficult life situations, experiencing culture and nature, having someone to love and lasting suffering. Moreover, meaning is also significantly related to quality of life, and the nurse-elderly interaction represents a substantial resource promoting elderly home residents' emotional and physical health and overall well-being ${ }^{(27)}$. In addition, institutionalized elders are vulnerable to loneliness and depression. Also, elders do not know what to do, what to think, what to say and also to cope with a series of losses. So, the nurses work in the elderly homes have an important role in helping the elderly to cope with these losses and provide the necessary care to meet the needs of elderly home residents.

\section{Limitations of the study}

Of the five available elderly homes in Dakahlia Governorate two refused to allow researchers to meet their residents. This led to the decrease in the number of elders fulfilling the study criteria who participated in the study.

\section{Conclusion}

Based on the findings of the present study, it can be concluded that interpersonal intimacy and meaning of life of institutionalized elderly are affected by the duration of stay in the home, the maintenance of social contact outside the elderly home and their perception about their health. Moreover, meaning of life, perceived health status and interpersonal intimacy are significantly related.

\section{Recommendations}

- Caregivers in elderly homes should focus on increasing interpersonal intimacy and purpose in life among their residents by increasing socialization and interaction among elders, encourage participation in recreational activities, plan periodical meeting with elder's family members and friends.

- Caregivers in the elderly home should encourage elders to maintain a social network inside and outside the home. Also, they should encourage the elders to maintain independence and autonomy.

- Design education and training programs for caregivers working in elderly homes to update their knowledge and skills about measures to increase interpersonal intimacy and meaning of life among elderly home residents in order to improve their quality of life.

- Further studies involving a large number of elders in different geographical areas are needed to confirm these findings. 


\section{Acknowledgement}

We would like to thank all the elders who accepted to participate in this study, the social workers and the directors of elderly homes for their cooperation.

Table (1): Distribution of the institutionalized elders according to their sociodemographic characteristics and presence of comorbidities

\begin{tabular}{|c|c|c|}
\hline Sociodemographic Characteristics & $\mathrm{N}=\mathbf{5 1}$ & $\%$ \\
\hline $\begin{array}{l}\text { Age (in years) } \\
60- \\
65- \\
70 \text { and more }\end{array}$ & $\begin{array}{l}13 \\
13 \\
25\end{array}$ & $\begin{array}{l}25.5 \\
25.5 \\
49.0\end{array}$ \\
\hline \multicolumn{3}{|c|}{ Mean \pm SD $=69.5 \pm 5.5$} \\
\hline $\begin{array}{l}\text { Sex } \\
\text { Male } \\
\text { Female }\end{array}$ & $\begin{array}{l}38 \\
13\end{array}$ & $\begin{array}{l}74.5 \\
25.5\end{array}$ \\
\hline $\begin{array}{l}\text { Religion } \\
\text { Muslim } \\
\text { Christian }\end{array}$ & $\begin{array}{l}38 \\
13\end{array}$ & $\begin{array}{l}74.5 \\
25.5\end{array}$ \\
\hline $\begin{array}{l}\text { Marital status } \\
\text { Widowed } \\
\text { Married } \\
\text { Divorced } \\
\text { Single } \\
\end{array}$ & $\begin{array}{c}29 \\
11 \\
6 \\
5\end{array}$ & $\begin{array}{l}56.8 \\
21.6 \\
11.8 \\
9.8\end{array}$ \\
\hline $\begin{array}{l}\text { Education level } \\
\text { Illiterate } \\
\text { Read and write } \\
\text { Secondary } \\
\text { University } \\
\end{array}$ & $\begin{array}{c}12 \\
6 \\
18 \\
15 \\
\end{array}$ & $\begin{array}{l}23.5 \\
11.8 \\
35.3 \\
29.4 \\
\end{array}$ \\
\hline $\begin{array}{l}\text { Occupation before retirement } \\
\text { Working } \\
\text { Not working }\end{array}$ & $\begin{array}{l}39 \\
12\end{array}$ & $\begin{array}{l}76.5 \\
23.5\end{array}$ \\
\hline $\begin{array}{l}\text { Monthly income } \\
\text { Enough } \\
\text { Not enough }\end{array}$ & $\begin{array}{l}38 \\
13\end{array}$ & $\begin{array}{l}74.5 \\
25.5\end{array}$ \\
\hline $\begin{array}{l}\text { Presence of comorbidities } \\
\text { No } \\
\text { one disease } \\
\text { Two diseases } \\
\text { More than two diseases }\end{array}$ & $\begin{array}{l}11 \\
19 \\
10 \\
11\end{array}$ & $\begin{array}{l}21.6 \\
37.2 \\
19.6 \\
21.6\end{array}$ \\
\hline
\end{tabular}

\# More than one answer 
Table (2): Distribution of institutionalized elders according to data about admission to the home and their satisfaction

\begin{tabular}{|l|c|c||}
\hline Item & $\mathbf{N = 5 1}$ & \% \\
\hline Decision of admission & 37 & 72.5 \\
Elders' decision & 14 & 27.5 \\
Family decision & 22 & 43.1 \\
\hline Reasons for admission & 11 & 21.6 \\
Absence of caregiver & 11 & 21.6 \\
Homeless & 7 & 13.7 \\
Feeling lonely & & \\
Family problems & 27 & 52.9 \\
\hline Feeling at the time of admission\# & 21 & 41.2 \\
Sad & 17 & 33.3 \\
Happy & & 70.6 \\
lonely & 36 & 29.4 \\
\hline Duration in the elderly home (in years) & 15 & 49.0 \\
$<5$ & & 39.2 \\
5- 10 & 25 & 29.4 \\
\hline Feeling now\# & 20 & 86.3 \\
Sad & 15 & 13.7 \\
Happy & & 68.6 \\
Lonely & 44 & 31.4 \\
\hline Elder satisfaction & 7 & \\
Yes & & \\
No & 35 & \\
\hline Taking leave outside the home & 16 & \\
Yes & & \\
No & & \\
\hline
\end{tabular}

\# More than one answer

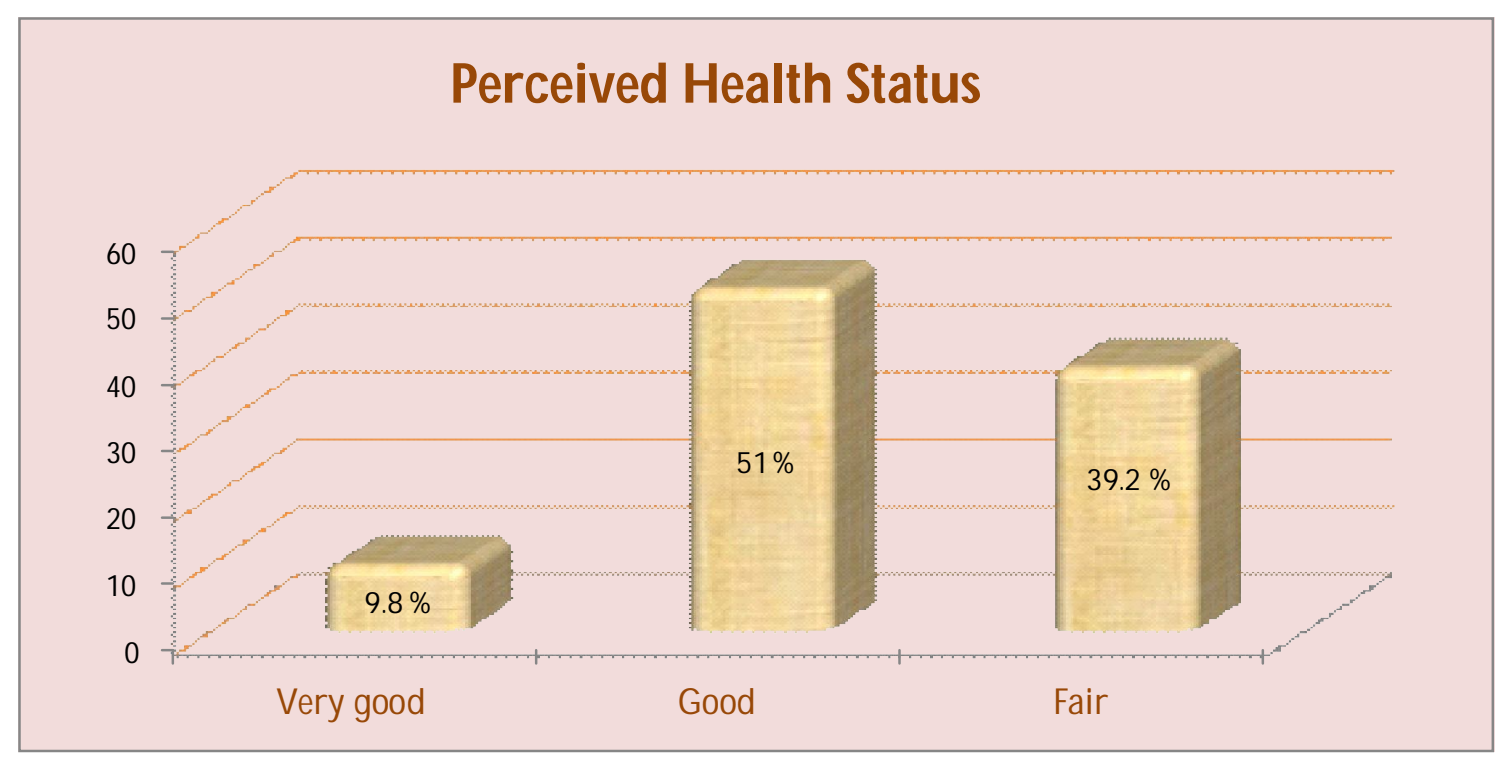

Figure (1): Perceived health status of institutionalized elders 
Table (3): Distribution of institutionalized elders according to their interpersonal intimacy responses $(\mathrm{N}=51)$

\begin{tabular}{||l|c|c|c|c|c|c||}
\hline \multirow{2}{*}{ Items } & \multicolumn{2}{|c|}{ Yes } & \multicolumn{2}{c||}{ Sometimes } & \multicolumn{2}{c||}{ No } \\
\cline { 2 - 7 } & N & \% & N & \% & N & \% \\
\hline The elderly home residents reported the following; & 11 & 21.6 & 28 & 54.9 & 12 & 23.5 \\
\hline Want to spend time together. & 20 & 39.2 & 26 & 51.0 & 5 & 9.8 \\
\hline Show their love for each other. & 31 & 60.8 & 14 & 27.5 & 6 & 11.8 \\
\hline Honest with and do not lie to each other. & 5 & 9.8 & 25 & 49.0 & 21 & 41.2 \\
\hline $\begin{array}{l}\text { Accept each other's criticism for faults and } \\
\text { mistakes. }\end{array}$ & 16 & 31.4 & 29 & 56.9 & 6 & 11.8 \\
\hline Love each other. & 26 & 51.0 & 21 & 41.2 & 4 & 7.8 \\
\hline Respect each other. & 25 & 49.0 & 20 & 39.2 & 6 & 11.8 \\
\hline Live is better because of each other. & 16 & 31.4 & 26 & 51.0 & 9 & 17.6 \\
\hline Enjoy the relationship. & 13 & 25.5 & 29 & 56.9 & 9 & 17.6 \\
\hline Cares about the way the elderly feel. & 13 & 25.5 & 22 & 43.1 & 16 & 31.4 \\
\hline Feel like a unit. & 18 & 35.3 & 24 & 47.1 & 9 & 17.6 \\
\hline $\begin{array}{l}\text { There is a great amount of unselfishness } \\
\text { relationship at elderly home. }\end{array}$ & 15 & 29.4 & 23 & 45.1 & 13 & 25.5 \\
\hline $\begin{array}{l}\text { Peers at home are prepared to sacrifice to each } \\
\text { other. }\end{array}$ & 13 & 25.5 & 31 & 60.8 & 7 & 13.7 \\
\hline $\begin{array}{l}\text { Peers at home always thinks of elder best } \\
\text { interest. }\end{array}$ & 19 & 37.3 & 25 & 49.0 & 7 & 13.7 \\
\hline Lucky to have such peers in life. & 14 & 27.5 & 27 & 52.9 & 10 & 19.6 \\
\hline Peers at home always make elder feel better. & 20 & 39.2 & 25 & 49.0 & 6 & 11.8 \\
\hline Peers at home are important. & 18 & 35.3 & 19 & 37.3 & 14 & 27.5 \\
\hline Sure, of this relationship. & & $\mathbf{1 9 . 4 9} \pm \mathbf{8 . 4 1}$ & & \\
\hline Mean score & & &
\end{tabular}

Table (4): Distribution of institutionalized elders' responses related to meaning of life $(\mathrm{N}=51)$

\begin{tabular}{|c|c|c|c|c|c|c|c|c|c|c|}
\hline \multirow[t]{2}{*}{ Items } & \multicolumn{2}{|c|}{$\begin{array}{l}\text { Absolutely } \\
\text { Untrue }\end{array}$} & \multicolumn{2}{|c|}{$\begin{array}{l}\text { Mostly } \\
\text { Untrue }\end{array}$} & \multicolumn{2}{|c|}{$\begin{array}{l}\text { Can't say } \\
\text { true or } \\
\text { false }\end{array}$} & \multicolumn{2}{|c|}{$\begin{array}{c}\text { Routinely } \\
\text { mostly } \\
\text { true }\end{array}$} & \multicolumn{2}{|c|}{$\begin{array}{l}\text { Absolutely } \\
\text { true }\end{array}$} \\
\hline & $\mathbf{N}$ & $\%$ & $\mathbf{N}$ & $\%$ & $\mathbf{N}$ & $\%$ & $\mathbf{N}$ & $\%$ & $\mathbf{N}$ & $\%$ \\
\hline \multicolumn{11}{|l|}{ Presence of meaning subscale: } \\
\hline I understand my life's meaning. & 17 & 33.3 & 7 & 13.7 & 13 & 25.5 & 9 & 17.6 & 5 & 9.8 \\
\hline My life has a clear sense of purpose. & 12 & 23.5 & 10 & 19.6 & 13 & 25.5 & 11 & 21.6 & 5 & 9.8 \\
\hline $\begin{array}{l}\text { I have a good sense of what makes my } \\
\text { life meaningful. }\end{array}$ & 15 & 29.4 & 12 & 23.5 & 14 & 27.5 & 5 & 9.8 & 5 & 9.8 \\
\hline $\begin{array}{llll}\text { I have discovered a satisfying life } \\
\text { purpose. }\end{array}$ & 13 & 25.5 & 20 & 39.2 & 8 & 15.7 & 7 & 13.7 & 3 & 5.9 \\
\hline My life has no clear purpose. & 2 & 3.9 & 8 & 15.7 & 18 & 35.3 & 14 & 27.5 & 9 & 17.6 \\
\hline \multicolumn{11}{|l|}{ Search of meaning subscale: } \\
\hline $\begin{array}{l}\text { I am looking for something that makes } \\
\text { my life feel meaningful. }\end{array}$ & 15 & 29.4 & 9 & 17.6 & 14 & 27.5 & 5 & 9.8 & 8 & 15.7 \\
\hline $\begin{array}{l}\text { I am always looking to find my life's } \\
\text { purpose. }\end{array}$ & 18 & 35.3 & 11 & 21.6 & 10 & 19.6 & 7 & 13.7 & 5 & 9.8 \\
\hline $\begin{array}{l}\text { I am always searching for something that } \\
\text { makes my life feel significant. }\end{array}$ & 12 & 23.5 & 10 & 19.6 & 21 & 41.2 & 4 & 7.8 & 4 & 7.8 \\
\hline $\begin{array}{l}\text { I am seeking a purpose or mission for my } \\
\text { life. }\end{array}$ & 10 & 19.6 & 17 & 33.3 & 13 & 25.5 & 7 & 13.7 & 4 & 7.8 \\
\hline I am searching for meaning in my life. & 9 & 17.6 & 12 & 23.5 & 19 & 37.3 & 6 & 11.8 & 5 & 9.8 \\
\hline Mean score & \multicolumn{10}{|c|}{$26.45 \pm 9.67$} \\
\hline
\end{tabular}


Table (5): Relation between sociodemographic characteristics of the institutionalized elders, and mean interpersonal intimacy and mean meaning of life $(\mathrm{N}=51)$

\begin{tabular}{|c|c|c|}
\hline Sociodemographic Characteristics & $\begin{array}{c}\text { Interpersonal Intimacy } \\
\text { Mean } \pm \text { SD }\end{array}$ & $\begin{array}{l}\text { Meaning of Life } \\
\text { Mean } \pm \text { SD }\end{array}$ \\
\hline $\begin{array}{l}\text { Age } \\
60- \\
65- \\
70 \text { and more }\end{array}$ & $\begin{array}{l}20.14 \pm 8.96 \\
19.69 \pm 8.27 \\
18.18 \pm 8.68\end{array}$ & $\begin{array}{l}29.29 \pm 11.05 \\
25.38 \pm 9.72 \\
25.36 \pm 7.57\end{array}$ \\
\hline Test of significance ( $P$ value) & $\mathrm{F}=0.177(0.838)$ & $\mathrm{F}=0.823(0.445)$ \\
\hline $\begin{array}{l}\text { Sex } \\
\text { Male } \\
\text { Female }\end{array}$ & $\begin{array}{l}21.21 \pm 8.20 \\
14.46 \pm 7.10\end{array}$ & $\begin{array}{l}28.66 \pm 9.81 \\
20.00 \pm 5.70\end{array}$ \\
\hline Test of significance ( $P$ value) & $\mathrm{T}=2.644(0.011)^{*}$ & $\mathrm{~T}=3.859(0.001)^{*}$ \\
\hline $\begin{array}{l}\text { Religion } \\
\text { Muslim } \\
\text { Christian }\end{array}$ & $\begin{array}{l}17.66 \pm 8.32 \\
24.85 \pm 6.27\end{array}$ & $\begin{array}{c}27.00 \pm 10.48 \\
24.85 \pm 6.89\end{array}$ \\
\hline Test of significance ( $P$ value) & $\mathrm{T}=2.843(0.006)^{*}$ & $\mathrm{~T}=0.689(0.494)$ \\
\hline $\begin{array}{l}\text { Marital status } \\
\text { Widowed } \\
\text { Married } \\
\text { Divorced } \\
\text { Single }\end{array}$ & $\begin{array}{c}17.69 \pm 8.16 \\
22.27 \pm 8.96 \\
20.50 \pm 10.45 \\
22.60 \pm 4.77\end{array}$ & $\begin{array}{c}25.45 \pm 9.16 \\
27.18 \pm 9.22 \\
29.00 \pm 12.65 \\
27.60 \pm 12.22\end{array}$ \\
\hline Test of significance ( $P$ value) & $\mathrm{F}=1.109(0.355)$ & $\mathrm{F}=0.275(0.843)$ \\
\hline $\begin{array}{l}\text { Education level } \\
\text { Illiterate } \\
\text { Read and write } \\
\text { Secondary } \\
\text { University }\end{array}$ & $\begin{array}{l}19.25 \pm 6.91 \\
18.33 \pm 8.59 \\
18.78 \pm 7.88 \\
21.0 \pm 10.45\end{array}$ & $\begin{array}{c}21.58 \pm 6.59 \\
26.33 \pm 8.54 \\
27.56 \pm 9.26 \\
29.06 \pm 11.85\end{array}$ \\
\hline Test of significance ( $P$ value) & $\mathrm{F}=0.234(0.872)$ & $\mathrm{F}=1.501(0.227)$ \\
\hline $\begin{array}{l}\text { Occupation before retirement } \\
\text { Working } \\
\text { Not working }\end{array}$ & $\begin{array}{l}21.31 \pm 8.24 \\
13.58 \pm 6.08\end{array}$ & $\begin{array}{l}28.49 \pm 9.95 \\
19.83 \pm 4.59\end{array}$ \\
\hline Test of significance ( $P$ value) & $\mathrm{T}=2.997(0.004)^{*}$ & $\mathrm{~T}=4.177(0.001)^{*}$ \\
\hline $\begin{array}{l}\text { Monthly income } \\
\text { Enough } \\
\text { Not enough }\end{array}$ & $\begin{array}{l}18.84 \pm 8.55 \\
21.38 \pm 7.99\end{array}$ & $\begin{array}{c}25.63 \pm 9.34 \\
28.85 \pm 10.61\end{array}$ \\
\hline Test of significance ( $P$ value) & $\mathrm{F}=1.809(0.004)^{*}$ & $\mathrm{~F}=3.284(0.04)^{*}$ \\
\hline $\begin{array}{l}\text { Presence of comorbidities } \\
\text { No } \\
\text { one disease } \\
\text { Two diseases } \\
\text { More than two diseases }\end{array}$ & $\begin{array}{c}20.0 \pm 3.60 \\
18.7 \pm 9.99 \\
18.2 \pm 5.76 \\
22.45 \pm 5.78\end{array}$ & $\begin{array}{c}38.3 \pm 12.42 \\
27.5 \pm 10.0 \\
22.8 \pm 7.9 \\
23.9 \pm 6.93\end{array}$ \\
\hline Test of significance ( $P$ value) & $\mathrm{F}=0.602(0.617)$ & $\mathrm{F}=2.056(0.066)$ \\
\hline
\end{tabular}

*Significant at $p \leq 0.05$ 
Table (6): Relation between elder's data about admission to and satisfaction in the home, and mean interpersonal intimacy and mean meaning of life

\begin{tabular}{|c|c|c|}
\hline Items & $\begin{array}{c}\text { Interpersonal Intimacy } \\
\text { Mean } \pm \text { SD }\end{array}$ & $\begin{array}{c}\text { Meaning of Life } \\
\text { Mean } \pm \text { SD }\end{array}$ \\
\hline $\begin{array}{l}\text { Decision of admission: } \\
\text { Elders' decision } \\
\text { Family decision }\end{array}$ & $\begin{array}{c}21.24 \pm 7.8 \\
14.85 \pm 8.56\end{array}$ & $\begin{array}{l}26.08 \pm 9.29 \\
27.42 \pm 10.9\end{array}$ \\
\hline Test of significance ( $P$ value) & $\mathrm{T}=2.47(0.017)^{*}$ & $\mathrm{~T}=0.917(0.364)$ \\
\hline $\begin{array}{l}\text { Reasons for admission } \\
\text { Absence of caregiver } \\
\text { Homeless } \\
\text { Feeling lonely } \\
\text { Family problems }\end{array}$ & $\begin{array}{c}20.83 \pm 8.13 \\
20.75 \pm 7.7 \\
16.55 \pm 11.75 \\
17.25 \pm 5.82\end{array}$ & $\begin{array}{c}23.5 \pm 8.51 \\
27.93 \pm 10.63 \\
33.44 \pm 9.08 \\
22.25 \pm 6.7\end{array}$ \\
\hline Test of significance ( $P$ value) & $\mathrm{F}=0.819(0.490)$ & $\mathrm{F}=3.103(0.036)^{*}$ \\
\hline $\begin{array}{l}\text { Feeling on admission: \# } \\
\text { Sad } \\
\text { Happy } \\
\text { lonely }\end{array}$ & $\begin{array}{c}16.78 \pm 10.6 \\
18.73 \pm 5.8 \\
23.17 \pm 6.5\end{array}$ & $\begin{array}{c}29.5 \pm 10.8 \\
25.86 \pm 10.7 \\
23.6 \pm 6.5\end{array}$ \\
\hline Test of significance ( $P$ value) & $\mathrm{F}=2.875(0.066)$ & $\mathrm{F}=1.75(0.185)$ \\
\hline $\begin{array}{l}\text { Duration of stay(in years) } \\
<5 \\
5-10 \text { years }\end{array}$ & $\begin{array}{l}21.61 \pm 6.97 \\
14.40 \pm 9.58\end{array}$ & $\begin{array}{c}26.61 \pm 9.64 \\
26.07 \pm 10.09\end{array}$ \\
\hline Test of significance ( $P$ value) & $\mathrm{F}=6.606(0.003)^{*}$ & $\mathrm{~F}=5.041(0.010)^{*}$ \\
\hline $\begin{array}{l}\text { Feeling now: \# } \\
\text { Sad } \\
\text { Happy } \\
\text { Lonely }\end{array}$ & $\begin{array}{l}24.5 \pm 7.7 \\
16.9 \pm 8.4 \\
17.9 \pm 7.6\end{array}$ & $\begin{array}{c}31.06 \pm 11.2 \\
26.5 \pm 9.6 \\
22.6 \pm 9.7\end{array}$ \\
\hline Test of significance ( $P$ value) & $\mathrm{F}=4.27(0.020)^{*}$ & $\mathrm{~F}=3.48(0.039)^{*}$ \\
\hline $\begin{array}{l}\text { Elder satisfaction } \\
\text { Yes } \\
\text { No }\end{array}$ & $\begin{array}{l}19.41 \pm 8.40 \\
18.00 \pm 8.83\end{array}$ & $\begin{array}{l}26.07 \pm 9.77 \\
24.00 \pm 6.73\end{array}$ \\
\hline Test of significance ( $P$ value) & $\mathrm{T}=0.320(0.750)$ & $\mathrm{T}=0.412(0.682)$ \\
\hline $\begin{array}{l}\text { Taking a leave outside the home } \\
\text { Yes } \\
\text { No }\end{array}$ & $\begin{array}{l}21.40 \pm 8.37 \\
15.31 \pm 7.06\end{array}$ & $\begin{array}{l}27.25 \pm 9.84 \\
26.09 \pm 9.72\end{array}$ \\
\hline Test of significance ( $P$ value) & $\mathrm{T}=2.525(0.015)^{*}$ & $\mathrm{~T}=0.395(0.694)$ \\
\hline
\end{tabular}

*Significant at $p \leq 0.05$

Table (7): Correlation between interpersonal intimacy, meaning of life and perceived health status among institutionalized elders

\begin{tabular}{|c|c|c|c|c|c|c|}
\hline \multirow[t]{2}{*}{ Items } & \multicolumn{2}{|c|}{$\begin{array}{c}\text { Interpersonal } \\
\text { Intimacy }\end{array}$} & \multicolumn{2}{|c|}{ Meaning of Life } & \multicolumn{2}{|c|}{$\begin{array}{c}\text { Perceived Health } \\
\text { Status }\end{array}$} \\
\hline & $\mathbf{r}$ & $\mathbf{P}$ & $\mathbf{r}$ & $\mathbf{P}$ & $\mathbf{r}$ & $\mathbf{P}$ \\
\hline Interpersonal Intimacy & - & - & 0.295 & $0.036^{*}$ & 0.105 & 0.463 \\
\hline Meaning of Life & 0.295 & $0.036^{*}$ & - & - & 0.273 & 0.052 \\
\hline Perceived Health Status & 0.105 & 0.463 & 0.273 & $0.05 *$ & - & - \\
\hline
\end{tabular}

*Significant at $p \leq 0.05$ 


\section{References}

1. Chiang, W. Y. An integrated model of suicidal ideation in senior veterans in an institute. Published Master's Thesis, Hsinchu, Taiwan: Hsuan Chuang University, 2011.

2. Niu, C. C., Huang, H. M., Hung, Y. Y., \& Lee, H. L. A Study of Interpersonal Intimacy and Meaning of Life Among Elderly Institutionalized Veterans. Journal of Nursing Research 2016;24(4): 311320 .

3. Chang, T. Y., \& Chueh, K. H. Relationship between elderly depression and health status in male veterans. Journal of Nursing Research 2011; 19(4): 298304.

4. Wu, P. W. A Study of the Relationships among Interpersonal Intimacy, Social Participation and Mental Health in Elders. Published Master's Dissertation, Taipei: National Taipei University of Education, 2011.

5. Hyun Cha, N., Ju Seo, E., \& Sok, S. R. Factors influencing the successful aging of older Korean adults. Contemporary Nurse 2012; 41(1): 78-87.

6. Calhoun, C., Donald, L., \& Suzanne, K. Understanding sociology (R. S., Lin, Trans.) Taipei City, Taiwan, ROC: Futaba. 2002.

7. Rampell, C. Bad news for older folks: Millennials are having fewer babies. 2015. Retrieved from The Washing Post. Available

at: https://www.washingtonpost.com.

8. Eliopoulos C. Gerontological nursing. $8^{\text {th }}$ ed., USA; Lippincott Williams \&Wilkins Company, 2014: 162-3.

9. Musich, S., Wang, S. S., Kraemer, S., Hawkins, K., \& Wicker, E. Purpose in Life and Positive Health Outcomes Among Older Adults. Population Health Management 2018; 21(2): 139-147.
10. Hedberg, P., Gustafson, Y., Brulin, C., \& Alex, L. Purpose in life among very old men. Advances in Aging Research 2013; 2(3): 100-105.

11. Hooker, S. A., \& Masters, K. S. Purpose in life is associated with physical activity measured by accelerometer. Journal of Health Psychology 2016; 21(6): 962-971.

12. Akbar, S., Tiwari, S. C., Tripathi, R. K., Kumar, A., \& Pandey, N. M. Reasons for Living of Elderly to In Old Age Homes: An Exploratory Study. The International Journal of Indian Psychology 2014; 2(1): 56-61.

13. Bayram, Z. Y., Oksüz, A. M., Turk, Y. A., \& Sagsoz, A. The Problems of theelderly in theuse of public spaces and their expectations: A Pilot Study in Trabzon (Turkey). International Journal of Academic Research 2011;3(3): 165173.

14. United Nations. World Population Ageing 2013. Available at: https://www.un.org.

15. United Nations, Department of Economic and Social Affairs, Population Division. World Population Ageing 2015. Available at: https://www.un.org.

16. World Health Organization. World report on aging and health 2015. Available at: https://www.who.int.

17. Meiner S. Gerontologic nursing. $5^{\text {th }}$ ed., USA: Elsevier Inc, 2015; 167-9.

18. Hoe, C. S., Kamarulzaman, W. B., \& Heang, L. T. Elderly People in Old Age Homes: Engaging Factors Leading to Institutionalization. International Academic Research Journal of Social Science 2018; 4(1): 28-41.

19. Audulv Å, Packer, T., Hutchinson, S., Roger KS, \& Kephart G. Coping, adapting or self-managing-what is the difference? A concept review based on 
the neurological literature. Journal of Advanced Nursing 2016; 72(11): 26292643.

20. Cress C. Handbook of geriatric care management. $4^{\text {th }}$ ed., USA: Jones and Bartlett publishers, 2017; 171.

21. Porter, E. J., Clinton, J. F., \& Munhall, P. L. Adjusting to the nursing home. Western Journal of Nursing Research 1992; 14(4): 464-481.

22. Riedl, M., Mantovan, F., \& Them, C. Being a nursing home resident: A challenge to one's identity. Nursing Research and Practice 2013.DOI: $10.1155 / 2013 / 932381$.

23. Long, K., \& Poi, P. Taking care of the elderly in Malaysia. 2014. Retrieved from The Star Online. Available at: http://www.thestar.com.

24. Reed PG. Theory of self-transcendence. In: Smith MJ, Liehr PR, editors. Middle range theory for nursing. $2^{\text {nd }}$ ed., New York: Springer, 2008; 105-29.

25. Travelbee J. Interpersonal aspects of nursing. $2^{\text {nd }}$ ed., Philadelphia, PA: F.A. Davis; 1979.

26. Dossey B, Keegan L. Holistic nursing: a handbook for practice. Jones and Bartlett: Sudbury, MA; 2009.

27. Drageset, J., Haugan, G., \& Tranvåg, O. Crucial aspects promoting meaning and purpose in life: perceptions of nursing home residents. BMC Geriatrics 2017; 17(1): 254.

28. Starck PL. Theory of meaning. In: Smith MJ, Liehr PR, editors. Middle range theory for nursing. $2^{\text {nd }}$ ed., New York: Springer, 2008; 81-104.

29. Mulawisha, G., \& Nyirenda, J. K. Interpersonal relations while caring for the elderly: Nurses' perspective. 2015. Available at: https://brage.bibsys.no.
30. Folstien, M. Mini-Mental State, a practical method for grading the cognitive state of patients for the clinician in clinical Gerontological Nursing: A Guide to Advanced Practice. $2^{\text {nd }}$ ed., London: WB Saunders Company. 1999.

31. El-Auqla, M. Prevalence of Alzheimer disease and other types of dementia in Egyptian elderly. Thesis, MD. University of Ain Shams, Faculty of Medicine. 2002.

32. Abd El Moniem, M. Comparative study of the effect of three types of restorative Nursing Interventions on the healthrelated functional status of geriatric patients with Parkinson's disease. Published Doctorate Thesis, University of Alexandria, Faculty of Nursing. 2012.

33. Chan, W. C., To, S. M., \& Wong, K. L. Intimacy as a distinct construct: Validating the Intimacy Scale among older adults of residential care homes in Hong Kong. The Open Family Studies Journal 2015; 7(1).

34. Steger, M. F., Frazier, P., Oishi, S., \& Kaler, M. The Meaning in Life Questionnaire: Assessing the presence of and search for meaning in life. Journal of Counseling Psychology 2006; 53: 80-93.

35. Hassan, W., Abd El-Halim, Z., Ahmed, S., Mostafa, N. Psychological Problems as Perceived by Institutionalized and Non-Institutionalized Elderly: Journal of Education and Practice 2017; (8)33.

36. Ahmed, M. Factors affecting loneliness among institutionalized and noninstitutionalized elders. Published Master Thesis, University of Mansoura, Faculty of Nursing. 2015.

37. Kalavar, J. M., \& Jamuna, D. Interpersonal relationships of elderly in selected old age homes in urban India. An International Journal on Personal Relationships 2008; 2(2): 193-215.

38. Rathaur, A., \& Mishra, S. Study on institutionalized and non-institutionalized 
elderly people. International Journal of Home Science 2016; 2(3): 77-79.

39. Gurung, S., \& Ghimire, S. Role of family in elderly care. Degree programme in nursing, LAPIN AMK: Lapland University of Applied Science 2014; (1): 7-51.

40. Singh, R., and Mahato, S. Coping strategies adopted by the institutionalized and non-institutionalized elderly in Kathmandu, Nepal: A comparative correlational study. Int J Res Dev Health 2014; 2 (1): 11-18.

41. Leslie Francis and Peter Kaldor, "The relationship between religion and purpose in life in an Australian Population Survey", Research in the Social Scientific Study of Religion 2001; 12: 53-63.

42. Liu, M. J. A study of the relationships among interpersonal intimacy, attachment style and well-being in elders. Published Master's Thesis, Kaohsiung, National Kaohsiung Normal University, Taiwan, ROC. 2000.

43. Teeri, S., Leino-Kilpi, H., \&Valmiki, M. Long-term nursing care of elderly people: identifying ethically problematic experiences among patients, relatives and nurses in Finland. Nursing Ethics 2006; 13(2): 116-129.
44. Hou, T. F. A study on the meaning of life, attitude toward death and quality of life among the senior veterans located in Yunlin and Chia-Yi. Published Master's Thesis. Nanhua University, Chiayi, Taiwan, ROC. 2004.

45. Waite, L., \& Das, A. Families, social life, and well-being at older ages. Demography 2010; 47(1): 87-109.

46. Wu, C. C., Huang, H. M., Kao, C. C., \& Kao, P. H. (2010). The autonomy and its related factors among older people in long-term care facilities. The Journal of Long-Term Care 2010; 14(1): 27-42.

47. Stillman, T. F., Baumeister, R. F., Lambert, N. M., Crescioni, A. W., DeWall, C. N., \& Fincham, F. D. Alone and without purpose: Life loses meaning following social exclusion. Journal of Experimental Social Psychology 2009; 45(4): 686-694. 